\title{
Reticulated Platelets-Which Functions Have Been Established by In Vivo and In Vitro Data?
}

\author{
Muataz Ali Hamad ${ }^{1,2,3, * \mathbb{C}}$, Nancy Schanze ${ }^{1}$, Nicolas Schommer ${ }^{1}{ }^{(\mathbb{D}}$, Thomas Nührenberg ${ }^{4}$ \\ and Daniel Duerschmied ${ }^{1}$ \\ 1 Department of Cardiology and Angiology I, Heart Center, Faculty of Medicine, University of Freiburg, \\ 79106 Freiburg im Breisgau, Germany; nancy.schanze@universitaets-herzzentrum.de (N.S.); \\ nicolas.schommer@universitaets-herzzentrum.de (N.S.); \\ daniel.duerschmied@universitaets-herzzentrum.de (D.D.) \\ 2 Spemann Graduate School of Biology and Medicine (SGBM), University of Freiburg, \\ 79104 Freiburg im Breisgau, Germany \\ 3 Faculty of Biology, University of Freiburg, 79104 Freiburg im Breisgau, Germany \\ 4 Department of Cardiology and Angiology II, Heart Center, Faculty of Medicine, University of Freiburg, \\ 79189 Bad Krozingen, Germany; thomas.nuehrenberg@uniklinik-freiburg.de \\ * Correspondence: muataz.ali.hamad@universitaets-herzzentrum.de; Tel.: +49-761-270-70470
}

Citation: Hamad, M.A.; Schanze, N.; Schommer, N.; Nührenberg, T.; Duerschmied, D. Reticulated Platelets-Which Functions Have Been Established by In Vivo and In Vitro Data?. Cells 2021, 10, 1172. https://doi.org/10.3390/cells10051172

Academic Editor: Peter Bugert

Received: 1 April 2021

Accepted: 10 May 2021

Published: 12 May 2021

Publisher's Note: MDPI stays neutral with regard to jurisdictional claims in published maps and institutional affiliations.

Copyright: (c) 2021 by the authors. Licensee MDPI, Basel, Switzerland. This article is an open access article distributed under the terms and conditions of the Creative Commons Attribution (CC BY) license (https:/ / creativecommons.org/licenses/by/ $4.0 /)$.

\begin{abstract}
Reticulated platelets (RP) are the youngest platelet fraction released into the circulation. These immature platelets have increased RNA content, a larger cell volume, more dense granules, higher levels of surface activation markers and are thought to be more reactive compared to their mature counterparts. RP have been associated with cardiovascular disease, diabetes and increased mortality. Yet only a few animal studies investigating RP have been conducted so far and further investigations are warranted. Established methods to count RP are flow cytometry (staining with thiazole orange or SYTO13) or fully automated hematology analyzers (immature platelet fraction, IPF). IPF has been established as a diagnostic parameter in thrombocytopenia, cardiovascular disease and, in particular, the response to antiplatelet therapy. This review seeks to provide an overview of the key features of RP as well as preanalytical and analytical aspects that need to be considered when working with this platelet population.
\end{abstract}

Keywords: reticulated platelets; immature platelets; immature platelet fraction

\section{Introduction}

Platelets are anucleate cell fragments derived from megakaryocytes (MK) in the bone marrow (BM) at a range of 150,000 to 400,000 cells / $\mu \mathrm{L}$ and play significant roles in hemostasis, thrombosis, and inflammation [1]. Reticulated platelets (RP) are the youngest platelets released into the circulation and contain a residual amount of megakaryocytederived RNA [2]. RP thus have increased RNA content compared to mature platelets and are characterized by a larger cell volume, more dense granules and higher levels of surface activation markers. They are considered to show increased reactivity and are associated with impaired response to antiplatelet therapy [2-4]. Higher levels of RP have been linked to a higher risk of major adverse cardiovascular events [5,6] and are associated with a higher risk of death in patients with acute coronary syndrome [7]. Platelets are refractory to many techniques that are commonly used in cell culture, which increases the need for animal models to manipulate and study platelets in different disease settings. The mouse model has been one of the most commonly used animal models to investigate platelets and serves to imitate a variety of pathological conditions. Murine and human platelets are functionally very similar with some differences in structure. While the usefulness of mouse models is clear, some inherent differences must be acknowledged and appreciated in the interpretation of the data. Here we will focus on the main considerations when studying murine platelets with special regard to the translational aspects of RP research. 


\section{Physiology of Reticulated Platelets}

Blood platelets are derived from bone marrow megakaryocytes via a process of MK cytoplasm remodeling which works in a largely similar manner in humans and mice. However, mouse MK contain more prominent demarcation membranes, consisting of supposedly preformed platelet territories [8]. The compartmentalization within the $\alpha$ granules of both human and murine platelets seems to be very similar which should be seen as further evidence that mouse platelets can mimic processes also present in human platelets [8]. Similarities between mouse and human platelets prevail, but a few distinctions should be acknowledged. In terms of hemostasis, one of the major differences is the platelet count $[9,10]$. On average murine platelet counts range three times higher than human platelet counts with variations across different mouse strains (average platelet count in mice is $1000-1500 \times 10^{3}$ cells $/ \mu \mathrm{L}$ ) [11]. Also, mouse platelets are smaller compared to human platelets (mean platelet volumes $4.7 \pm 0.3 \mathrm{fl}$ in mice vs. $7.5-10 \mathrm{fl}$ in humans) [12]. Besides these structural differences, the circulating life-span of mouse platelets is markedly shorter than that of human platelets (3-4 days in mice vs. 8-12 days in humans) [13]. Since part of the murine thrombopoiesis takes part in megakaryocytes in the spleen, this could further add to the higher platelet turnover observed in mice [14]. As RP comprise the youngest platelets in the circulation, they are referred to as 'reticulated', analogous to reticulocytes in erythropoiesis [15]. In the bone marrow, RP are about 2-3 times higher than in peripheral blood [16]. Through the higher amount of RNA in RP one can distinguish them from mature platelets using adequate staining and analyze them in a quantitative manner [14]. RP are present for $\leq 24 \mathrm{~h}$ in humans, whereas in mice they were identifiable for 1.5 days [17]. While in humans, RP account for about $5 \%$ of the total platelet population in a steady-state [18], in mice they make up around $7 \%$ of the total platelet count [19]. In rats, one study even showed a mean RP percentage of $10 \%$ [17]. Mean platelet volume (MPV) is a measure of platelet size. RP are larger than mature platelets, as shown by animal studies as well as in humans after chemotherapy [20-22]. It is important to notice that these measurements were done under conditions with increased platelet turnover, during which the ploidy of megakaryocytes increases [23], leading to the observation of increased platelet size together with the ploidy of megakaryocytes [24] and supporting the concept of larger young platelets when turnover increases.

On the other hand, platelet size may not correlate with platelet age under steady state platelet production and clearance. A study of healthy adults using the Abbott Sapphire analyzer highlighted a negative association between RP and MPV [25], suggesting that an increased platelet size does not correlate well with platelet age under steady state platelet generation in humans. When platelet turnover increases, larger young platelets are produced, likely because alternative pathways of platelet production are triggered [26]. Although RP might be larger in size than mature platelets, the morphological properties of $\mathrm{RP}$ are difficult to observe mainly due to the lack of suitable markers and their relatively low presence in total platelets [18]. Figure 1 summarizes different RP properties and roles. 


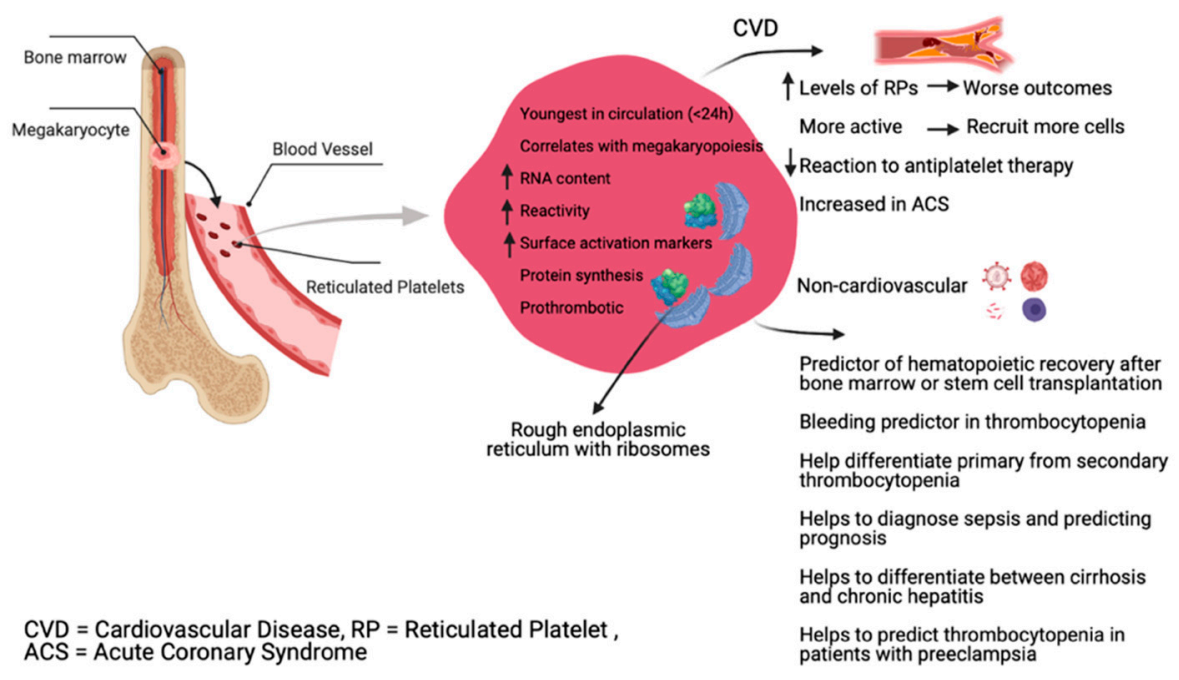

Figure 1. RP properties and roles in different diseases.

\section{Pre-Analytical Aspects}

Platelets can be easily activated; hence to perform accurate in vitro platelet assays it is important to ensure that sample collection does not lead to platelet activation. The small size of mice and their limited blood volume highly increase the chance of platelet activation during blood withdrawal. Blood can be collected using different methods in mice and choosing the right or suitable route depends on different factors such as the amount of blood to be collected, the frequency of blood collection and the size or nature of the collection tool. Blood can be collected from the retrobulbar venous plexus, jugular vein, carotid artery, inferior vena cava, heart, tail, or lateral saphenous veins (Table 1).

Table 1. Different blood collection routes from mice.

\begin{tabular}{ccccc}
\hline Route & Blood Volume & Collection Tool & Endpoint & Notes \\
\hline $\begin{array}{c}\text { Retrobulbar } \\
\text { venous }\end{array}$ & $\sim 0.5 \mathrm{~mL}$ & $\begin{array}{c}\sim 1.5 \mathrm{~cm} \text { long } \\
\text { glass capillary. }\end{array}$ & Sacrifice the animal. & $\begin{array}{c}\text { Blood contact with glass can } \\
\text { activate platelets. }\end{array}$ \\
\hline $\begin{array}{c}\text { Cardiac } \\
\text { puncture }\end{array}$ & $\sim 1 \mathrm{~mL}$ & $\begin{array}{c}\text { T G needle and } \\
\text { a syringe. }\end{array}$ & $\begin{array}{c}\text { Sacrifice the animal. } \\
\text { lead to thrombin generation and } \\
\text { platelet activation. }\end{array}$ \\
\hline $\begin{array}{c}\text { Inferior vena } \\
\text { cava }\end{array}$ & $\sim 1.2 \mathrm{~mL}$ & $\begin{array}{c}22-27 \text { G needle and } \\
\text { a syringe. }\end{array}$ & Sacrifice the animal. & $\begin{array}{c}\text { This method probably results in } \\
\text { the least platelet activation. }\end{array}$ \\
\hline Tail veins & Up to $\sim 50 \mu \mathrm{LL}$ & $\begin{array}{c}\text { Horizontal incision in } \\
\text { the tail vein. }\end{array}$ & $\begin{array}{c}\text { Suggested for multiple } \\
\text { blood collection. }\end{array}$ & $\begin{array}{c}\text { Milking' the tail should be } \\
\text { avoided to avoid higher } \\
\text { erythrocyte and leukocyte count in } \\
\text { the sample. }\end{array}$ \\
\hline
\end{tabular}

The blood volume of an average mouse $(\sim 25 \mathrm{~g})$ is $\sim 1.8 \mathrm{~mL}$, and adult mice tolerate the withdrawal of up to $0.7 \mathrm{~mL}$ and recover their normal blood volume within $24 \mathrm{~h}$ [27]. Blood is collected into a tube containing an anticoagulant and all the anticoagulants used in human platelet studies have been successfully used for mice platelets. Choosing the appropriate agent depends on the ultimate goal of the platelet study involved. Blood collection in mice is usually done under general anesthesia, which can be achieved using different agents and routes [28]. The commonly used routes are intraperitoneally (sodium pentobarbital, ketamine, avertin) or inhalation (isoflurane) [28]. Even though no reports show any effect of anesthesia on platelet function in mice, parenteral anesthesia has been shown to decrease platelet aggregation and inhibit the release reaction in both humans and animals [28]. Thus, anesthesia with isoflurane should be the preferred mode for the collection of platelets in 
mice. As for other hematological parameters, RP/IPF are normally measured in blood samples collected into K2-EDTA. Citrate-theophylline-adenosine-dipyridamole solution (CTAD) might be preferred over EDTA in some cases, such as when using a Sysmex XE-5000, as a study reported more stable IPF in blood from patients with chronic ITP [29]. Stability and storage temperature before analysis is method dependent but in general, a slight increase occurs during $24 \mathrm{~h}$ in EDTA-anticoagulated blood samples at room temperature. Using different automated analyzers, the values in human blood were stable within $6 \mathrm{~h}$ after blood collection at room temperature [30], while for Mindray BC-6800 stability was shown within $8 \mathrm{~h} \mathrm{[31].} \mathrm{When} \mathrm{platelets} \mathrm{collected} \mathrm{from} \mathrm{one} \mathrm{animal} \mathrm{are} \mathrm{not} \mathrm{sufficient} \mathrm{in} \mathrm{number,} \mathrm{it} \mathrm{may}$ be necessary to collect blood from multiple animals [5-15] for one experiment. Platelets are isolated from whole blood for most of the assays in the form of platelet-rich plasma (PRP). The preparation of PRP can be done in different ways; either using one-step centrifugation, or sequential centrifugation of plasma and buffy coat [32]. PRP usually still contains a few leukocytes which contaminate some assays, such as RNA-Seq of platelets for which leukocyte depletion should be performed. This can either be achieved by magnetic beads covalently coupled to anti-CD45 antibodies or by filtration through specific membranes. For platelet research, certainly the magnetic 'no-touch' techniques are preferable to avoid undesired platelet activation.

\section{Pathogens}

To ensure reproducibility of research it is required to have laboratory animals free of disease and other conditions that could interfere with the observed outcomes. Mice are prone to infections and these infections even if they are subclinical may influence animals physiology and immunity which in turn might have effects on platelets. A good example of these pathogens is Helicobacter hepaticus which is a known 'unwanted' pathogen present in rodent colonies [33]. A recent study from the University of Rio de Janeiro for instance examined mice from their animal facilities for Helicobacter spp. showing that $~ 59 \%$ of fecal and $\sim 70 \%$ of intestinal samples were positive for this pathogen [33].

\section{Methods for Reticulated Platelets Determination}

\subsection{Flow Cytometry}

The most commonly used method to evaluate RP is flow cytometry (FCM) with nucleic acid binding fluorochromes such as thiazole orange (TO) or SYTO13. The higher RNA content in RP makes it possible to discriminate these from mature platelets when staining against RNA with a nucleic acid-specific dye. TO is such a nucleic acid-specific dye that exhibits several thousand-fold increases in fluorescence emission upon binding to RNA or DNA [34]. TO is excitable at $488 \mathrm{~nm}$ which makes it suitable for most flow cytometers, easily permeates the cell membrane, and has a high quantum yield when bound to nucleic acids. When used in RP studies, there is a direct dose-response relationship between the amount of TO added and the number of RP observed, reaching a plateau at $5 \mu \mathrm{g}$ TO per $5 \mu \mathrm{L}$ of whole blood, while $12 \mu \mathrm{g}$ was found to be the optimum [19]. Increasing the amount of TO would produce a population shift or mean channel shift that needs to be accounted for when setting gates for TO positive events [19]. Using a platelet-specific antibody (such as CD41, CD61) combined with TO is therefore an accurate method of counting RP.

The nucleic acid dye SYTO 13 is an alternative for staining RP which proves to have several advantages over TO [35]. SYTO13 shows high stability over time, facilitating extended experimental analysis (for instance making it more suitable for sorting) and higher quantum yield. For both dyes, it is important to note that nonspecific labeling may occur by staining of mitochondria or dense granules with both dyes.

\subsection{Fully Automated Analyzers}

Besides FCM, automated cell counters have been developed to measure human RP as a fraction of the total platelet count such as the Sysmex hematology analyzer, Abbott CELL-DYN Sapphire, and Mindray analyzer. 


\subsubsection{Sysmex Analyzers}

The Sysmex XE-2100 and 5000 hematology analyzers allow the counting of RP together with reticulocytes using dedicated software and fluorescent dye (polymethine). The immature platelet fraction (IPF) is expressed as both a percentage of total platelets (\%IPF) and in the absolute count (\#IPF). The new generation of the Sysmex device (XN) uses a specific platelet channel (PLT-F), and a different fluorescent dye (phenoxazine) [36]. Some studies have compared the two generations $\mathrm{XE}$ and $\mathrm{XN}$ and concluded that the $\mathrm{XN}$ generation has higher and broader reference intervals of \%IPF [37-39]. The \%IPF in adult, healthy humans range from $0.7-10.1$ with some sex-specific reference intervals [22-24]. The concept that both generations of analyzers use is the measuring of forward scatter (cell volume) and fluorescence intensity (RNA content), and a computer algorithm discriminates between the mature and immature platelets on these bases.

\subsubsection{Abbott Analyzer}

The Abbott CELL-DYN Sapphire is a hematology analyzer capable of measuring RPs. The measurement of RP is based on the fluorescent dye CD4K530 as part of the reticulocyte assay. The platelets are separated from the red blood cells by recording three angles of scattered light plus fluorescence. The algorithm used defines RPs in a scatterplot of FL1 versus light at a $7^{\circ}$ angle [25].

\subsubsection{Mindray Analyzer}

The Mindray BC-6800 measures IPF by asymmetric cyanine-based dye for staining RNA. IPF is expressed as a percentage and is derived from forward scatter vs. sideward fluorescence scatterplot. The IP/RP can be reported as an absolute number $\left(\times 10^{9} / \mathrm{L}\right)$ calculated by multiplying the platelet count by the value percentage [31].

$\mathrm{RP}$ are often investigated in more detail using flow cytometry. IPF is obtained with automated hematology analyzers. The term "young platelets" is more descriptive. These values when compared show a modest correlation with a similar but numerically different trend. The different results obtained with different methods may be attributed to several analytical and pre-analytical reasons. The used stains (solution ready to use or homepreparation), contamination from other blood cells such as leukocyte or the unspecific binding of the dyes and, the different gating strategies are all possible explanations for the differences between the results obtained with different methods. For instance, the flow cytometer gate is usually set at $1 \%$, while for Sysmex it is proprietary and not modifiable [31]. Therefore, although the terms RP and IPF are frequently considered synonymous, in practice the two parameters cannot be used interchangeably and it is important to distinguish between them as they only partially overlap [30].

In basic research, if mouse platelets are analyzed using automated cell counters that are designed for human platelets, it is necessary to adjust the discriminators due to the smaller size. Very low platelet counts might be attributed to improper blood collection or improper adjustments on the automated cell counters. Another variable that might affect platelet counting is the presence of cellular fragments with a size similar to platelets.

\section{In Vivo Data}

\subsection{Animal Studies}

RP in Diabetes and Increased CVD Risk

Diabetes is one of the major risk factors for cardiovascular disease (CVD) [40], with atherosclerosis as a major driver [41,42]. Yet the underlying mechanisms of how hyperglycemia accelerates atherogenesis still remain widely unresolved. Given that reticulated platelets act in a hyperreactive manner and have been associated with increased CVR, it is of great importance to investigate the role of these immature platelets in diabetes. In one study, diabetes was induced in C57BL6 mice using streptozotocin, a toxin which destroys the beta cells in the pancreas [43]. Interestingly these diabetic mice had increased $\mathrm{RP}$, platelet-leukocyte aggregates, and elevated leukocyte activation and proliferation. 
Increased production/proliferation of platelet progenitors is associated with diabetes resulting in elevated circulating levels of highly activated RP. To take a closer look at the reason behind such findings, the livers of diabetic mice were examined. The diabetic mice were found to have increased Kupffer cell population in the liver and a high proportion of these cells produce interleukin 6 (IL-6), a proinflammatory cytokine. Increased IL-6 production was a response to hyperglycemia as the neutrophil-derived S100 calcium-binding proteins A8/A9 (S100A8/A9) interact with the receptor of advanced glycosylation end products (RAGE) on hepatic Kupffer cells. IL-6 increases thrombopoietin which in turn interacts with platelet progenitor cells leading to increased RP production. This hypothesis was tested by either chemical depletion of Kupffer cells or genetic knockout of IL-6 resulting in reduced RP in the diabetic mice. Obese mice (diet-induced or due to genetic background $(o b / o b)$ had more IL-6 production by Kupffer cells and more RP than lean mice. To test whether hyperglycemia is responsible for these findings, diabetic mice's blood glucose levels were reduced. This resulted in normalization of RP levels and Kupffer cells produced lower amounts of IL-6. Depleting neutrophils or Kupffer cells, or inhibiting S100A8/ A9 binding to RAGE, reduced diabetes-induced thrombocytosis. The authors then examined some of these parameters in a cohort of people with type 2 diabetes. Patients with diabetes and peripheral vascular disease taking aspirin had increased levels of RP and platelet-monocyte-aggregates compared to healthy controls taking aspirin. The authors concluded that glycosylated hemoglobin, as well as increased plasma levels of S100A8/A9 correlate with reticulated thrombocytosis in DM-2 patients. These findings provide insights into the mechanisms that regulate platelet production and may help to improve current antiplatelet therapies.

\subsection{Clinical Utility of $R P$}

The immature platelet fraction (IPF) or RP has numerous clinical applications in diagnosing and monitoring different diseases. The clinical applications of IPF and RP are summarized in (Table 2).

Table 2. Clinical applications of IPF and RP.

\begin{tabular}{|c|c|c|}
\hline Proposed Clinical Applications & Intended Goal & Reference \\
\hline Thrombocytopenia & $\begin{array}{l}\text { Differentiating platelets hypoproduction from } \\
\text { accelerated destruction }\end{array}$ & [44-48] \\
\hline $\begin{array}{l}\text { Bone marrow/stem cells transplantation } \\
\text { or chemotherapy }\end{array}$ & Predicting platelet recovery & [49-53] \\
\hline Myelodysplastic syndromes & Clinical evaluation and assessing prognosis & {$[49,50]$} \\
\hline Cardiovascular diseases & Assessing the role of platelet activation in prognosis & {$[51-53]$} \\
\hline Antiplatelet therapy & Predicting treatment response & {$[52,54]$} \\
\hline Infectious diseases & Early diagnosis & [55] \\
\hline Sepsis & Predicting sepsis in critically ill patients & {$[56,57]$} \\
\hline Pregnancy complications & Monitoring preeclampsia & [58] \\
\hline Liver diseases & $\begin{array}{c}\text { Differential diagnosis between cirrhosis and } \\
\text { chronic hepatitis }\end{array}$ & [59-61] \\
\hline
\end{tabular}

\subsubsection{Thrombocytopenia}

The causes of thrombocytopenia are diverse and sometimes difficult to confirm. The main question in any thrombocytopenia case is the determination of the underlying cause: is it related to bone marrow failure or peripheral causes? RP/IPF is a useful parameter in differentiating between thrombocytopenia due to bone marrow failure in which the proportion of RP is within the reference range, or thrombocytopenia due to peripheral destruction or acute blood loss in which the proportion is increased [30,44-48]. A strong correlation 
was detected between platelet count and IPF in primary immune thrombocytopenia (ITP). In ITP patients, the median IPF value ranges from 5.7-22.3\%. In aplastic anemia (AA) with an isolated thrombocytopenia presentation, IPF has been shown to increase [37]. The sensitivity and specificity of \%IPF in differentiating between ITP and AA are 54\% and 92\%, respectively, with \%IPF of $7.3 \%$ as the best cut-off [37]. In chemotherapy patients who had fewer platelet transfusions, an increase in IPF occurred after 2-3 days indicating platelet recovery [62].

The increase in IPF is a crucial observation that can prevent unnecessary platelet transfusion and may serve as an indicator for successful engraftment after stem cell transplantation [63-66].

\subsubsection{Myelodysplastic Syndromes}

IPF is also a useful marker in some myelodysplastic syndromes, as a high IPF is associated with poorer prognosis due to megakaryocytic dysplasia or karyotypic abnormalities [49,50].

\subsubsection{Cardiovascular Disease and Antiplatelet Therapy}

High IPF in patients with coronary artery disease has been reported in several studies, especially with acute coronary syndrome (ACS) [51,67-70]. More specifically, higher levels of RP have been linked to a higher risk of major adverse cardiovascular events [51,68-71] and are associated with a higher risk of death in patients with ACS [72]. In patients with ST segment elevation myocardial infraction (STEMI), RP were increased four-fold compared to control patients [73]. Not only in relation to healthy controls, another study showed that RPs were particularly elevated in STEMI patients compared to other types of acute coronary syndromes [70]. An interesting aspect in which RP might have a significant role is myocardial ischemia/reperfusion (I/R) injury, which is the tissue damage caused when blood supply returns to tissue after a period of ischemia. I/R injury is caused by the interventional reopening of an occluded coronary vessel in the context of MI. The platelet population as a whole during I/R has been investigated in the past, but the role of platelet subpopulations still remains unclear. The response of RP to antiplatelet therapy is of great interest, because RP seem to exhibit resistance to common antiplatelet therapies at least to some extent [74]. In ACS, patients received antiplatelet therapy with aspirin and $\mathrm{P}_{2} \mathrm{Y}_{12}$ antagonists (clopidogrel/prasugrel or ticagrelor) as a mono- or dual-therapy for the prevention of thromboembolic complications. It is uncertain whether the reduced drug effect is due to a stronger RP reactivity or due to an increase in newly formed platelets.

\subsubsection{Infection Diagnosis and Control}

A relationship between IPF and infection has been reported. IPF was found to be a useful tool in detecting an infectious state, and it was sensitive enough to differentiate a serious from a minor infection [55]. Depending on the patients' clinical condition, IPF varied, and values below 5.5\% showed normalization of body temperature by 2-7 days [55]. In sepsis, a significant correlation between higher IPF and the diagnosis of sepsis was established [57]. A decrease in IPF\# was an independent predictor of severe thrombocytopenia and mortality [57]. Other researchers have concluded that IPF could predict sepsis development before symptoms appear [56]. Another interesting finding was that the HIV viral load correlated with IPF, which might be attributed to a secondary HIV-driven platelet activation [75]. IPF can also predict platelet recovery 24-48 h earlier in dengue infection [76].

\subsubsection{Pregnancy Complications}

Pregnancy is associated with an increase in IPF, usually between 20 and 40 weeks of gestation. An increase in IPF of more than 7.5\% suggests increased thrombopoiesis in response to increased platelet consumption [77]. IPF values are significantly higher in patients with gestational hypertension when compared to normotensive pregnancy $[58,78]$. Changes in IPF may be predictive of the development of thrombocytopenia in patients with preeclampsia, as there is a correlation between higher IPF and lower platelet count [58]. 


\subsubsection{Liver Diseases}

Hepatitis B or C patients who are thrombocytopenic have elevated IPF when compared to nonthrombocytopenic infected patients $[79,80]$. On the other hand, patients with liver cirrhosis have higher IPF values than patients with chronic hepatitis [59-61], thus allowing for differential diagnosis between cirrhosis and chronic hepatitis.

\section{In Vitro Data}

High on-treatment platelet reactivity and reoccurrence of thrombotic events represent a major therapeutic hurdle when attempting to prevent thrombotic complications. Besides several pathological states linked to high on-treatment platelet reactivity, an increased rate of platelet turnover is a major contributing factor. A study in which the interactions of populations of platelets from healthy volunteers and patients with stable cardiovascular disease were followed in vitro showed an overproportion of RP in the core of the aggregates being formed [54]. These findings indicate that RP are more reactive, have a greater propensity for recruitment to thrombi, and "act as seeds" for platelet aggregate formation [60]. More importantly, this phenomenon was particularly observed in samples from patients treated with aspirin plus a thienopyridine, but was absent in samples taken from patients treated with aspirin plus ticagrelor. Another study to investigate the influence of RP on cangrelor and transitioning strategies to oral P2Y12-receptor inhibitors found a detectable correlation between RP and platelet reactivity in patients receiving thienopyridines, but not ticagrelor [52]. During treatment with aspirin plus thienopyridine, the short pharmacokinetic half-lives of these drugs may explain this phenomenon, while during treatment with ticagrelor, which has a longer half-life and ability to act as a circulating inhibitor, this phenomenon is absent. This suggests that newly formed and somewhat drug-resistant RP play a key role in limiting the effectiveness of antiplatelet therapies.

\section{Conclusions}

In conclusion, the youngest RPs in the circulation are more reactive and show greater tendency to recruit other platelets and immune cells to the site of injury. Containing residual RNA makes it possible to stain RPs and differentiate them from reticulocytes and mature platelets. RPs have been associated with higher CVR in ACSs, major adverse outcomes and, most importantly, increased mortality. Not only do they spike in STEMI and all forms of MI, but diabetes also promotes reticulated thrombopoiesis. Additionally, IPF is utilized as a disease and prognosis modifying parameter in a variety of different conditions. Whether $\mathrm{RP} / \mathrm{IPFs}$ only serve as prognostic markers or whether RPs themselves are drivers of disease and pose a targetable threat still needs to be investigated in depth. Only a few animal studies on RP have been carried out to this day and most of our current knowledge is derived from observational studies in humans. Although mouse platelets are in many ways similar to those of humans, there are still some questions to be raised when using murine platelets, for example, whether platelets isolated from different sites are similar or whether the method of collection can influence platelet activation. Further considerations limiting research reproducibility are potential differences across strains or the presence of undesirable pathogens. Nevertheless, mouse models have successfully mimicked human diseases and have provided insights into their underlying pathology. Interpreting the results as relevant to a specific experimental setting is crucial and there is no 'best' model for every study.

Author Contributions: Conceptualization, M.A.H. and D.D.; methodology, M.A.H.; writing—original draft preparation, all authors; writing - review and editing, all authors; supervision, T.N. and D.D. All authors have read and agreed to the published version of the manuscript.

Funding: This study is part of SFB1425, funded by the Deutsche Forschungsgemeinschaft (DFG, German Research Foundation \#422681845).

Conflicts of Interest: The authors declare no conflict of interest. 


\section{References}

1. Clark, V.L.; Kruse, J.A. Clinical Methods: The History, Physical, and Laboratory Examinations, 3rd ed.; Walker, H.K., Hall, W.D., Hurst, J.W., Eds.; Butterworths: Boston, MA, USA, 1990; ISBN 978-0-409-90077-4.

2. Muronoi, T.; Koyama, K.; Nunomiya, S.; Lefor, A.K.; Wada, M.; Koinuma, T.; Shima, J.; Suzukawa, M. Immature platelet fraction predicts coagulopathy-related platelet consumption and mortality in patients with sepsis. Thromb. Res. 2016, 144, 169-175. [CrossRef]

3. Wong, C.H.Y.; Jenne, C.N.; Petri, B.; Chrobok, N.L.; Kubes, P. Nucleation of platelets with blood-borne pathogens on Kupffer cells precedes other innate immunity and contributes to bacterial clearance. Nat. Immunol. 2013, 14, 785-792. [CrossRef]

4. Barsam, S.J.; Psaila, B.; Forestier, M.; Page, L.K.; Sloane, P.A.; Geyer, J.T.; Villarica, G.O.; Ruisi, M.M.; Gernsheimer, T.B.; Beer, J.H.; et al. Platelet production and platelet destruction: Assessing mechanisms of treatment effect in immune thrombocytopenia. Blood 2011, 117, 5723-5732. [CrossRef]

5. Hoffmann, J.J.M.L. Reticulated platelets: Analytical aspects and clinical utility. Clin. Chem. Lab. Med. 2014, 52, 1107-1117. [CrossRef]

6. Ts'ao, C.H. Rough endoplasmic reticulum and ribosomes in blood platelets. Scand. J. Haematol. 1971, 8, 134-140. [CrossRef] [PubMed]

7. Angénieux, C.; Maître, B.; Eckly, A.; Lanza, F.; Gachet, C.; de la Salle, H. Time-Dependent Decay of mRNA and Ribosomal RNA during Platelet Aging and Its Correlation with Translation Activity. PLoS ONE 2016, 11, e0148064. [CrossRef]

8. Schmitt, A.; Guichard, J.; Massé, J.M.; Debili, N.; Cramer, E.M. Of mice and men: Comparison of the ultrastructure of megakaryocytes and platelets. Exp. Hematol. 2001, 29, 1295-1302. [CrossRef]

9. Jackson, C.W.; Steward, S.A.; Chenaille, P.J.; Ashmun, R.A.; McDonald, T.P. An analysis of megakaryocytopoiesis in the C3H mouse: An animal model whose megakaryocytes have 32N as the modal DNA class. Blood 1990, 76, 690-696. [CrossRef] [PubMed]

10. Levin, J.; Ebbe, S. Why are recently published platelet counts in normal mice so low? Blood 1994, 83, 3829-3831. [CrossRef] [PubMed]

11. Fukuda, T.; Asou, E.; Nogi, K.; Goto, K. Evaluation of mouse red blood cell and platelet counting with an automated hematology analyzer. J. Vet. Med. Sci. 2017, 79, 1707-1711. [CrossRef] [PubMed]

12. Corash, L.; Chen, H.Y.; Levin, J.; Baker, G.; Lu, H.; Mok, Y. Regulation of thrombopoiesis: Effects of the degree of thrombocytopenia on megakaryocyte ploidy and platelet volume. Blood 1987, 70, 177-185. [CrossRef] [PubMed]

13. Rasmussen, T.V.; Ahlen, M.T. Murine models for studying treatment, prevention and pathogenesis of FNAIT. Transfus. Apher. Sci. 2020, 59, 102706. [CrossRef]

14. Ault, K.A.; Knowles, C. In Vivo biotinylation demonstrates that reticulated platelets are the youngest platelets in circulation. Exp. Hematol. 1995, 23, 996-1001. [PubMed]

15. Ault, K.A.; Rinder, H.M.; Mitchell, J.; Carmody, M.B.; Vary, C.P.; Hillman, R.S. The significance of platelets with increased RNA content (reticulated platelets). A measure of the rate of thrombopoiesis. Am. J. Clin. Pathol. 1992, 98, 637-646. [CrossRef] [PubMed]

16. Stohlawetz, P.; Schulenburg, A.; Stiegler, G.; Panzer, S.; Höcker, P.; Kalhs, P.; Schwarzinger, I.; Müllauer, L.; Simonitsch, I.; Geissler, K.; et al. The proportion of reticulated platelets is higher in bone marrow than in peripheral blood in haematological patients. Eur. J. Haematol. 1999, 63, 239-244. [CrossRef]

17. Pankraz, A.; Ledieu, D.; Pralet, D.; Provencher-Bolliger, A. Detection of reticulated platelets in whole blood of rats using flow cytometry. Exp. Toxicol. Pathol. Off. J. Ges. Toxikol. Pathol. 2008, 60, 443-448. [CrossRef] [PubMed]

18. Kono, M.; Matsuhiroya, S.; Nakazawa, F.; Kaido, M.; Wada, A.; Tomiyama, Y. Morphological and optical properties of human immature platelet-enriched population produced in immunodeficient mice. Platelets 2019, 30, 652-657. [CrossRef] [PubMed]

19. Kern, B.; Molineux, G.; Briddell, R. A method for the determination of the number of reticulated platelets from whole blood. Exp. Hematol. 2000, 28, 92. [CrossRef]

20. Detwiler, T.C.; Odell, T.T.; MacDONALD, T.P. Platelet size, ATP content, and clot retraction in relation to platelet age. Am. J. Physiol. 1962, 203, 107-110. [CrossRef] [PubMed]

21. Martin, J.F.; Trowbridge, E.A.; Salmon, G.; Plumb, J. The biological significance of platelet volume: Its relationship to bleeding time, platelet thromboxane B2 production and megakaryocyte nuclear DNA concentration. Thromb. Res. 1983, 32, 443-460. [CrossRef]

22. Balduini, C.L.; Noris, P.; Spedini, P.; Belletti, S.; Zambelli, A.; Da Prada, G.A. Relationship between size and thiazole orange fluorescence of platelets in patients undergoing high-dose chemotherapy. Br. J. Haematol. 1999, 106, 202-207. [CrossRef] [PubMed]

23. Mazzi, S.; Lordier, L.; Debili, N.; Raslova, H.; Vainchenker, W. Megakaryocyte and polyploidization. Exp. Hematol. 2018, 57, 1-13 [CrossRef] [PubMed]

24. Bessman, J.D. The relation of megakaryocyte ploidy to platelet volume. Am. J. Hematol. 1984, 16, 161-170. [CrossRef] [PubMed]

25. Hoffmann, J.J.M.L.; van den Broek, N.M.A.; Curvers, J. Reference intervals of reticulated platelets and other platelet parameters and their associations. Arch. Pathol. Lab. Med. 2013, 137, 1635-1640. [CrossRef] [PubMed]

26. Handtke, S.; Thiele, T. Large and small platelets-(When) do they differ? J. Thromb. Haemost. JTH 2020, 18, 1256-1267. [CrossRef] [PubMed]

27. Golde, W.T.; Gollobin, P.; Rodriguez, L.L. A rapid, simple, and humane method for submandibular bleeding of mice using a lancet. Lab Anim. 2005, 34, 39-43. [CrossRef] [PubMed] 
28. Parasuraman, S.; Raveendran, R.; Kesavan, R. Blood sample collection in small laboratory animals. J. Pharmacol. Pharmacother. 2010, 1, 87-93. [CrossRef] [PubMed]

29. Nishiyama, M.; Hayashi, S.; Kabutomori, O.; Yamanishi, H.; Suehisa, E.; Kurata, Y.; Kashiwagi, H.; Tomiyama, Y. Effects of anticoagulants and storage temperature on immature platelet fraction \% (IPF\%) values in stored samples measured by the automated hematology analyzer, XE-5000-utility of CTAD-anticoagulation and room temperature storage. Rinsho Byori. Jpn. J. Clin. Pathol. 2011, 59, 452-458.

30. Meintker, L.; Haimerl, M.; Ringwald, J.; Krause, S.W. Measurement of immature platelets with Abbott CD-Sapphire and Sysmex XE-5000 in haematology and oncology patients. Clin. Chem. Lab. Med. 2013, 51, 2125-2131. [CrossRef]

31. Buttarello, M.; Mezzapelle, G.; Freguglia, F.; Plebani, M. Reticulated platelets and immature platelet fraction: Clinical applications and method limitations. Int. J. Lab. Hematol. 2020, 42, 363-370. [CrossRef]

32. Etulain, J.; Mena, H.A.; Meiss, R.P.; Frechtel, G.; Gutt, S.; Negrotto, S.; Schattner, M. An optimised protocol for platelet-rich plasma preparation to improve its angiogenic and regenerative properties. Sci. Rep. 2018, 8, 1513. [CrossRef]

33. Matos-Rodrigues, G.E.; Masseron, C.C.; Silva, F.J.M.D.; Frajblat, M.; Moreira, L.O.; Martins, R.A.P. PCR-based detection of Helicobacter spp. in animal facilities of a University in Rio de Janeiro, Brazil. An. Acad. Bras. Cienc. 2020, 92, e20191517. [CrossRef] [PubMed]

34. Robinson, M.; MacHin, S.; Mackie, I.; Harrison, P. In vivo biotinylation studies: Specificity of labelling of reticulated platelets by thiazole orange and mepacrine. Br. J. Haematol. 2000, 108, 859-864. [CrossRef] [PubMed]

35. Hille, L.; Cederqvist, M.; Hromek, J.; Stratz, C.; Trenk, D.; Nührenberg, T.G. Evaluation of an Alternative Staining Method Using SYTO 13 to Determine Reticulated Platelets. Thromb. Haemost. 2019, 119, 779-785. [CrossRef]

36. Wada, A.; Takagi, Y.; Kono, M.; Morikawa, T. Accuracy of a New Platelet Count System (PLT-F) Depends on the Staining Property of Its Reagents. PLoS ONE 2015, 10, e0141311. [CrossRef] [PubMed]

37. Jung, H.; Jeon, H.-K.; Kim, H.-J.; Kim, S.-H. Immature platelet fraction: Establishment of a reference interval and diagnostic measure for thrombocytopenia. Korean J. Lab. Med. 2010, 30, 451-459. [CrossRef]

38. Ali, U.; Knight, G.; Gibbs, R.; Tsitsikas, D.A. Reference intervals for absolute and percentage immature platelet fraction using the Sysmex XN-10 automated haematology analyser in a UK population. Scand. J. Clin. Lab. Investig. 2017, 77, 658-664. [CrossRef]

39. Morkis, I.V.C.; Farias, M.G.; Scotti, L. Determination of reference ranges for immature platelet and reticulocyte fractions and reticulocyte hemoglobin equivalent. Rev. Bras. Hematol. E Hemoter. 2016, 38, 310-313. [CrossRef]

40. Haffner, S.M.; Lehto, S.; Rönnemaa, T.; Pyörälä, K.; Laakso, M. Mortality from coronary heart disease in subjects with type 2 diabetes and in nondiabetic subjects with and without prior myocardial infarction. N. Engl. J. Med. 1998, 339, 229-234. [CrossRef]

41. Lüscher, T.F.; Creager, M.A.; Beckman, J.A.; Cosentino, F. Diabetes and vascular disease: Pathophysiology, clinical consequences, and medical therapy: Part II. Circulation 2003, 108, 1655-1661. [CrossRef] [PubMed]

42. Pasterkamp, G. Methods of accelerated atherosclerosis in diabetic patients. Heart Br. Card. Soc. 2013, 99, 743-749. [CrossRef]

43. Kraakman, M.J.; Lee, M.K.S.; Al-Sharea, A.; Dragoljevic, D.; Barrett, T.J.; Montenont, E.; Basu, D.; Heywood, S.; Kammoun, H.L.; Flynn, M.; et al. Neutrophil-derived S100 calcium-binding proteins A8/A9 promote reticulated thrombocytosis and atherogenesis in diabetes. J. Clin. Investig. 2017, 127, 2133-2147. [CrossRef]

44. Sakuragi, M.; Hayashi, S.; Maruyama, M.; Kabutomori, O.; Kiyokawa, T.; Nagamine, K.; Kato, H.; Kashiwagi, H.; Kanakura, Y.; Tomiyama, Y. Clinical significance of IPF\% or RP\% measurement in distinguishing primary immune thrombocytopenia from aplastic thrombocytopenic disorders. Int. J. Hematol. 2015, 101, 369-375. [CrossRef] [PubMed]

45. Pons, I.; Monteagudo, M.; Lucchetti, G.; Muñoz, L.; Perea, G.; Colomina, I.; Guiu, J.; Obiols, J. Correlation between immature platelet fraction and reticulated platelets. Usefulness in the etiology diagnosis of thrombocytopenia. Eur. J. Haematol. 2010, 85, 158-163. [PubMed]

46. Kienast, J.; Schmitz, G. Flow cytometric analysis of thiazole orange uptake by platelets: A diagnostic aid in the evaluation of thrombocytopenic disorders. Blood 1990, 75, 116-121. [CrossRef] [PubMed]

47. Briggs, C.; Kunka, S.; Hart, D.; Oguni, S.; Machin, S.J. Assessment of an immature platelet fraction (IPF) in peripheral thrombocytopenia. Br. J. Haematol. 2004, 126, 93-99. [CrossRef] [PubMed]

48. Cybulska, A.; Meintker, L.; Ringwald, J.; Krause, S.W. Measurements of immature platelets with haematology analysers are of limited value to separate immune thrombocytopenia from bone marrow failure. Br. J. Haematol. 2017, 177, 612-619. [CrossRef]

49. Larruzea Ibarra, A.; Muñoz Marín, L.; Perea Durán, G.; Torra Puig, M. Evaluation of immature platelet fraction in patients with myelodysplastic syndromes. Association with poor prognosis factors. Clin. Chem. Lab. Med. 2019, 57, e128-e130. [CrossRef]

50. Sugimori, N.; Kondo, Y.; Shibayama, M.; Omote, M.; Takami, A.; Sugimori, C.; Ishiyama, K.; Yamazaki, H.; Nakao, S. Aberrant increase in the immature platelet fraction in patients with myelodysplastic syndrome: A marker of karyotypic abnormalities associated with poor prognosis. Eur. J. Haematol. 2009, 82, 54-60. [CrossRef]

51. Cesari, F.; Marcucci, R.; Gori, A.M.; Caporale, R.; Fanelli, A.; Casola, G.; Balzi, D.; Barchielli, A.; Valente, S.; Giglioli, C.; et al. Reticulated platelets predict cardiovascular death in acute coronary syndrome patients. Insights from the AMI-Florence 2 Study. Thromb. Haemost. 2013, 109, 846-853. [CrossRef] [PubMed]

52. Stratz, C.; Nührenberg, T.; Valina, C.; Löffelhardt, N.; Mashayekhi, K.; Ferenc, M.; Trenk, D.; Neumann, F.-J.; Hochholzer, W. Impact of Reticulated Platelets on the Antiplatelet Effect of the Intravenous P2Y12-Receptor Inhibitor Cangrelor. Thromb. Haemost. 2018, 118, 362-368. [CrossRef] 
53. McBane, R.D.; Gonzalez, C.; Hodge, D.O.; Wysokinski, W.E. Propensity for young reticulated platelet recruitment into arterial thrombi. J. Thromb. Thrombolysis 2014, 37, 148-154. [CrossRef]

54. Armstrong, P.C.; Hoefer, T.; Knowles, R.B.; Tucker, A.T.; Hayman, M.A.; Ferreira, P.M.; Chan, M.V.; Warner, T.D. Newly Formed Reticulated Platelets Undermine Pharmacokinetically Short-Lived Antiplatelet Therapies. Arterioscler. Thromb. Vasc. Biol. 2017, 37, 949-956. [CrossRef]

55. Liu, Q.-H.; Song, M.-Y.; Yang, B.-X.; Xia, R.-X. Clinical significance of measuring reticulated platelets in infectious diseases. Medicine 2017, 96, e9424. [CrossRef]

56. De Blasi, R.A.; Cardelli, P.; Costante, A.; Sandri, M.; Mercieri, M.; Arcioni, R. Immature platelet fraction in predicting sepsis in critically ill patients. Intensive Care Med. 2013, 39, 636-643. [CrossRef]

57. Koyama, K.; Katayama, S.; Muronoi, T.; Tonai, K.; Goto, Y.; Koinuma, T.; Shima, J.; Nunomiya, S. Time course of immature platelet count and its relation to thrombocytopenia and mortality in patients with sepsis. PLoS ONE 2018, 13, e0192064. [CrossRef]

58. Everett, T.R.; Garner, S.F.; Lees, C.C.; Goodall, A.H. Immature platelet fraction analysis demonstrates a difference in thrombopoiesis between normotensive and preeclamptic pregnancies. Thromb. Haemost. 2014, 111, 1177-1179. [CrossRef] [PubMed]

59. Nomura, T.; Kubota, Y.; Kitanaka, A.; Kurokouchi, K.; Inage, T.; Saigo, K.; Iseki, K.; Baba, N.; Yamaoka, G.; Arai, T.; et al. Immature platelet fraction measurement in patients with chronic liver disease: A convenient marker for evaluating cirrhotic change. Int. J. Lab. Hematol. 2010, 32, 299-306. [CrossRef]

60. Kim, H.R.; Park, B.R.G.; Lee, M.K.; Park, A.J.; Ahn, J.Y. Comparison of an immature platelet fraction and reticulated platelet in liver cirrhosis. Korean J. Lab. Med. 2007, 27, 7-12. [CrossRef] [PubMed]

61. Rauber, P.; Lammert, F.; Grotemeyer, K.; Appenrodt, B. Immature platelet fraction and thrombopoietin in patients with liver cirrhosis: A cohort study. PLoS ONE 2018, 13, e0192271. [CrossRef] [PubMed]

62. Gonçalo, A.P.; Barbosa, I.L.; Campilho, F.; Campos, A.; Mendes, C. Predictive value of immature reticulocyte and platelet fractions in hematopoietic recovery of allograft patients. Transplant. Proc. 2011, 43, 241-243. [CrossRef]

63. Takami, A.; Shibayama, M.; Orito, M.; Omote, M.; Okumura, H.; Yamashita, T.; Shimadoi, S.; Yoshida, T.; Nakao, S.; Asakura, H. Immature platelet fraction for prediction of platelet engraftment after allogeneic stem cell transplantation. Bone Marrow Transplant. 2007, 39, 501-507. [CrossRef]

64. Saigo, K.; Sakota, Y.; Masuda, Y.; Matsunaga, K.; Takenokuchi, M.; Nishimura, K.; Sugimoto, T.; Sakurai, K.; Hashimoto, M.; Yanai, T.; et al. Automatic detection of immature platelets for decision making regarding platelet transfusion indications for pediatric patients. Transfus. Apher. Sci. Off. J. World Apher. Assoc. Off. J. Eur. Soc. Haemapheresis 2008, 38, 127-132. [CrossRef] [PubMed]

65. Have, L.W.J.; Hasle, H.; Vestergaard, E.M.; Kjaersgaard, M. Absolute immature platelet count may predict imminent platelet recovery in thrombocytopenic children following chemotherapy. Pediatr. Blood Cancer 2013, 60, 1198-1203. [CrossRef] [PubMed]

66. Morkis, I.V.C.; Farias, M.G.; Rigoni, L.D.C.; Scotti, L.; Gregianin, L.J.; Daudt, L.E.; Silla, L.M.d.R.; Paz, A.A. Assessment of immature platelet fraction and immature reticulocyte fraction as predictors of engraftment after hematopoietic stem cell transplantation. Int. J. Lab. Hematol. 2015, 37, 259-264. [CrossRef]

67. Ibrahim, H.; Nadipalli, S.; Usmani, S.; DeLao, T.; Green, L.; Kleiman, N.S. Detection and quantification of circulating immature platelets: Agreement between flow cytometric and automated detection. J. Thromb. Thrombolysis 2016, 42, 77-83. [CrossRef]

68. Gonzalez-Porras, J.R.; Martin-Herrero, F.; Gonzalez-Lopez, T.J.; Olazabal, J.; Diez-Campelo, M.; Pabon, P.; Alberca, I.; San Miguel, J.F. The role of immature platelet fraction in acute coronary syndrome. Thromb. Haemost. 2010, 103, 247-249. [CrossRef] [PubMed]

69. López-Jiménez, R.A.; Martín-Herrero, F.; González-Porras, J.R.; Sánchez-Barba, M.; Martín-Luengo, C.; Pabón-Osuna, P. Immature Platelet Fraction: A New Prognostic Marker in Acute Coronary Syndrome. Rev. Esp. Cardiol. Engl. Ed. 2013, 66, 147-148. [CrossRef] [PubMed]

70. Grove, E.L.; Hvas, A.-M.; Kristensen, S.D. Immature platelets in patients with acute coronary syndromes. Thromb. Haemost. 2009, 101, 151-156.

71. Tscharre, M.; Farhan, S.; Bruno, V.; Rohla, M.; Egger, F.; Weiss, T.W.; Hübl, W.; Willheim, M.; Wojta, J.; Geppert, A.; et al. Impact of platelet turnover on long-term adverse cardiovascular outcomes in patients undergoing percutaneous coronary intervention. Eur. J. Clin. Investig. 2019, 49, e13157. [CrossRef]

72. Ibrahim, H.; Schutt, R.C.; Hannawi, B.; DeLao, T.; Barker, C.M.; Kleiman, N.S. Association of immature platelets with adverse cardiovascular outcomes. J. Am. Coll. Cardiol. 2014, 64, 2122-2129. [CrossRef]

73. Lakkis, N.; Dokainish, H.; Abuzahra, M.; Tsyboulev, V.; Jorgensen, J.; De Leon, A.P.; Saleem, A. Reticulated platelets in acute coronary syndrome: A marker of platelet activity. J. Am. Coll. Cardiol. 2004, 44, 2091-2093. [CrossRef] [PubMed]

74. Stratz, C.; Bömicke, T.; Younas, I.; Kittel, A.; Amann, M.; Valina, C.M.; Nührenberg, T.; Trenk, D.; Neumann, F.-J.; Hochholzer, W. Comparison of Immature Platelet Count to Established Predictors of Platelet Reactivity During Thienopyridine Therapy. J. Am. Coll. Cardiol. 2016, 68, 286-293. [CrossRef] [PubMed]

75. Vaughan, J.; Wiggill, T.; Munster, M. Immature platelet fraction levels in a variety of bone marrow pathologies in South African HIV-positive patients with thrombocytopenia. Hematology 2014, 19, 417-423. [CrossRef] [PubMed]

76. Dadu, T.; Sehgal, K.; Joshi, M.; Khodaiji, S. Evaluation of the immature platelet fraction as an indicator of platelet recovery in dengue patients. Int. J. Lab. Hematol. 2014, 36, 499-504. [CrossRef]

77. Ratsch, U.; Kaiser, T.; Stepan, H.; Jank, A. Evaluation of bone marrow function with immature platelet fraction in normal pregnancy. Pregnancy Hypertens. 2017, 10, 70-73. [CrossRef] 
78. Bernstein, U.; Kaiser, T.; Stepan, H.; Jank, A. The immature platelet fraction in hypertensive disease during pregnancy. Arch. Gynecol. Obs. 2019, 299, 1537-1543. [CrossRef]

79. Zucker, M.L.; Hagedorn, C.H.; Murphy, C.A.; Stanley, S.; Reid, K.J.; Skikne, B.S. Mechanism of thrombocytopenia in chronic hepatitis $C$ as evaluated by the immature platelet fraction. Int. J. Lab. Hematol. 2012, 34, 525-532. [CrossRef]

80. Dou, J.; Lou, Y.; Wu, J.; Lu, Y.; Jin, Y. Thrombocytopenia in patients with hepatitis B virus-related chronic hepatitis: Evaluation of the immature platelet fraction. Platelets 2014, 25, 399-404. [CrossRef] 